\title{
Control of Meloidogyne incognita in tomato plants with highly diluted solutions of Thuya occidentalis and their effects on plant growth and defense metabolism
}

\author{
Controle de Meloidogyne incognita em tomateiro com soluções \\ ultradiluídas de Thuya occidentalis e seus efeitos no crescimento e \\ metabolismo de defesa da planta
}

\author{
Thaísa Muriel Mioranza ${ }^{1 *}$; José Renato Stangarlin²; Mônica Anghinoni Müller³; \\ Sidiane Coltro-Roncato ${ }^{4}$; Adriano Mitio Inagaki ${ }^{4}$; Cristiane Claudia Meinerz ${ }^{5}$; \\ Rogério Lopes Estevez ${ }^{6}$; Rafael Augusto Swarowsky ${ }^{7}$; \\ Bruna Caroline Schons ${ }^{8}$; Odair José Kuhn²
}

\begin{abstract}
This work aimed to control the root-knot nematode Meloidogyne incognita in tomato Solanum lycopersicum L plants with high-diluted solutions of Thuya occidentalis, and to study its effects on growth and plant defense responses. The in vivo experiment was carried out over two years (2013 and 2014) at a climatized greenhouse, whilst the in vitro experiment was carried out in the laboratory. Eight treatments were used $[6,12,24,50,100,200$ and $400 \mathrm{CH}$ (Hahnemannian centesimal) of T. occidentalis, with water as control treatment]. For the in vivo assay, in 2013 plants were inoculated with about 4850 eggs and second-stage juveniles (J2), while in 2014 they were inoculated with 5050 eggs and J2. The treatments were applied once a week, as $0.1 \%$ aqueous solutions onto the plant shoots, for 50 and 40 days respectively. For the in vitro experiment, the nematodes were directly exposed to the same $0.1 \%$ treatments. The treatments did not show nematostatic or nematicide effects in the in vitro assay, and had no influence on the hatching of the eggs. For the in vivo assay in 2013, T. occidentalis $100 \mathrm{CH}$ decreased the number of $\mathbf{J} 2$ present in the roots, whilst the dynamization of $200 \mathrm{CH}$ stimulated root development and increased the weight of the fruits of the first cluster. In $2014,100 \mathrm{CH}$ decreased numbers of J2 in the soil. Some dynamization increased the plant's defense enzyme activity, such as peroxidase $(24,50$, 200 and $400 \mathrm{CH})$, polyphenoloxidase $(200 \mathrm{CH})$, and phenylalanine ammonia-lyase $(24$ and $50 \mathrm{CH})$. In this study, T. occidentalis $100 \mathrm{CH}$ showed potential for the control of M. incognita, whilst 24 and $200 \mathrm{CH}$ influenced the growth of plants.
\end{abstract}

Key words: Alternative control. Crop protection. Homeopathy. Resistance induction. Root-knot nematode. Solanum lycopersicum L.

\footnotetext{
${ }^{1}$ Discente, Curso de Doutorado em Agronomia, Universidade Estadual de Maringá, UEM/PGA, Maringá, PR, Brasil. E-mail: thaisamioranza@hotmail.com

2 Profs. Drs., Universidade Estadual do Oeste do Paraná, Departamento de Agronomia, Centro de Ciências Agrárias, Unioeste, Marechal Cândido Rondon, PR, Brasil. E-mail: jose.stangarlin@unioeste.br; ojkuhn@gmail.com

${ }^{3}$ Discente, Curso de Doutorado em Agronomia, Universidade Federal do Paraná, UFPR/PPGA, Curitiba, PR. E-mail: mo_ang@, hotmail.com

${ }^{4}$ Pós-Doutorado em Agronomia, Unioeste, Marechal Cândido Rondon, PR, Brasil. E-mail: scoltr@hotmail.com; mitioinagaki@ gmail.com

5 Pós-Doutorado em Ciências Ambientais, Unioeste, Marechal Cândido Rondon, PR, Brasil. E-mail: crismeinerz@hotmail.com

${ }^{6}$ Discente, Curso de Doutorado em Agronomia, Unioeste, Marechal Cândido Rondon, PR, Brasil. E-mail: estevezpr@hotmail.com

7 M.e em Agronomia, Unioeste, Marechal Cândido Rondon, PR, Brasil. E-mail: rafael.spock@gmail.com

8 Discente, Curso de Agronomia, Departamento de Agronomia, Centro de Ciências Agrárias, Unioeste, Marechal Cândido Rondon, PR, Brasil. E-mail: bru.schons@hotmail.com

* Author for correspondence
} 


\section{Resumo}

O objetivo desse trabalho foi controlar o nematoide de galhas Meloidogyne incognita em tomateiro com soluções ultradiluídas de Thuya occidentalis e estudar seus efeitos no crescimento da planta e nas respostas de defesa vegetal. O experimento in vivo foi realizado em dois anos, 2013 e 2014, e desenvolvido em casa de vegetação climatizada, enquanto o in vitro foi realizado em laboratório. Utilizaram-se oito tratamentos $[6,12,24,50,100,200$ e 400CH (centesimal Hahnemaniana) de $T$. occidentalis e água como controle]. Para o ensaio in vivo, em 2013 foram inoculados aproximadamente 4850 ovos e juvenis de segundo estágio (J2) enquanto em 2014 foram inoculados 5050 ovos e J2. Os tratamentos foram diluídos para $0,1 \%$ com água destilada e foram aplicados uma vez por semana na parte aérea das plantas por 50 e 40 dias respectivamente aos anos de condução. No experimento in vitro, os nematoides ficaram expostos diretamente aos tratamentos também na concentração de $0,1 \%$. Os tratamentos não mostraram efeito nematostático e nematicida no ensaio in vitro, assim como não influenciaram na eclosão de juvenis. Para os ensaios in vivo em 2013, T. occidentalis na dinamização de $100 \mathrm{CH}$ reduziu a população de $\mathrm{J} 2$ nas raízes, e a dinamização de $200 \mathrm{CH}$ incrementou o crescimento da planta, aumentando o volume de raiz e massa fresca de frutos do primeiro cacho. Em 2014, o tratamento $100 \mathrm{CH}$ diminuiu o número de $\mathrm{J} 2$ no solo. Algumas dinamizações aumentaram a atividade de enzimas de defesa vegetal, como peroxidase $(24,50,200$ e $400 \mathrm{CH})$, polifenoloxidase $(200 \mathrm{CH})$ e fenilalanina amônia-liase (24 e 50CH). Nesse estudo, T. occidentalis $100 \mathrm{CH}$ apresentou potencial para controle de M. incognita, bem como 24 e $200 \mathrm{CH}$ influenciam no crescimento das plantas.

Palavras-chave: Controle alternativo. Homeopatia. Indução de resistência. Nematoide das galhas. Proteção de plantas. Solanum lycopersicum.

The nematodes of genus Meloidogyne, popularly known as root-knot nematodes, are difficult to control because they use a wide range of hosts. The specie M. incognita (KOFOID; WHITE, 1919) Chitwood, 1949 possibly causes the greatest damage to crops globally, because it is able to rapidly increase its population in susceptible hosts such as the tomato Solanum lycopersicum L (MOENS et al., 2009). These nematodes penetrate the plant roots and promote hypertrophy and hyperplasia of the plant cells, forming galls. This impairs the uptake of water and nutrients by the roots, resulting in reduction of plant growth and production. Furthermore, the injuries caused by the penetration of the nematodes facilitate infection by other pathogens present in the soil (FERRAZ; MONTEIRO, 2011).

Soil root-knot nematode populations are managed and reduced via integrated control methods, such as crop rotation, use of resistant cultivars, and physical, biological, and chemical controls. However, these methods have some limitations, such as the relatively small number of resistant plants that are economically important enough to be used in crop rotation. Other potential problems include the difficulty of implementation of physical controls (such as soil solarization or soil inundation over large areas), the high cost of biological products, and the presence of agrochemical residues in food and in the environment when synthetic nematicides are used (WESEMAEL et al., 2011).

Normally, tomatoes cultivated under conventional systems of production are constantly treated with synthetic organic pesticides against pests and diseases, putting the balance of environment and human health at risk (MODOLON et al., 2012). To reduce the effects of the indiscriminate use of pesticides on both human health and the environment, an alternative method of plant disease control, utilizing the induction of resistance via natural products, has been highlighted (STANGARLIN et al., 2011).

The use of homeopathy in agriculture to manage diseases and pests in organic production system is permitted by Brazilian law. This method uses highly diluted and dynamized solutions for this purpose (CARNEIRO et al., 2011). 
Homeopathic preparations have been reported to induce resistance in plants against pests and diseases, and to improve the adaptation of plants to adverse environmental conditions, harmonizing the relationship between the environment and plants, as well as improving the crop's productivity (ROSSI et al., 2004).

The use of highly diluted solutions in agriculture has been tested in various pathosystems, including Phytophthora infestans in tomato (DINIZ et al., 2006), Alternaria solani (CARNEIRO et al., 2010) and Septoria lycopersici (MODOLON et al., 2012) in tomato, Sclerotinia sclerotiorum in common bean (RISSATO et al., 2016), and Macrophomina phaseolina in soybean (LORENZETTI et al., 2016). Similar work has been done for nematode control, as reported by Sukul et al. (2013) and Swarowsky et al. (2014), which used several dynamizations of Cina in cucumber and tomato plants, respectively, to control M. incognita.

According to Bonato (2007), plant physiology permits the description of symptoms of disease and physiological signals in terms of their similarity to those observed in humans, aiding in the choice of homeopathic preparations for plants on the basis of these similarities. Thuya occidentalis is used as a homeopathic treatment of skin and mucosal warts, pedunculated warts, ulcers, and herpetic eruptions in humans (BOERICKE, 2003; NASER et al., 2005). Symptoms of these diseases resemble those caused by root-knot nematodes in plants, i.e. hypertrophy and hyperplasia of affected cells (KARSSEN et al., 2013).

Therefore, the aim of this work was to evaluate the control of $M$. incognita in tomato plants using seven dilutions of a homeopathic extract of $T$. occidentalis, and to verify the effects on plant growth, and on the biochemical responses of plant defense.

The assays were performed in two consecutive years, from October to November of 2013, and from September and October of 2014, in a greenhouse, with temperatures between 26 to $28{ }^{\circ} \mathrm{C}$. The assays of 2013 were performed using a completely randomized design, whilst the 2014 assay was performed using a randomized block design. Both years used eight treatments with four replicates.

The treatments were chosen according to the repertoire of symptoms observed in plants, which were associated with symptoms seen in humans (BONATO, 2007), as described by the Manual de Matéria Médica Homeopática (Handbook of Homeopathic Medical Materials) (BOERICKE, 2003). The treatments consisted of homeopathic preparations of $T$. occidentalis, as listed in the Homeopathic Materia Medica, and acquired in the dynamizations of $6,12,24,50,100,200$ and $400 \mathrm{CH}$ (Hahnemanian centesimal). The control treatment was distilled water. The $T$. occidentalis for these dynamizations were obtained at a homeopathic pharmacy, diluted according to the centesimal scale, via the Hahnemannian method. According this method, 1 part of homeopathic preparation was diluted in 99 parts of $30 \%$ ethanol, followed by 100 successions, in accordance with the Brazilian Homeopathic Pharmacopoeia (FHB, 2011).

'Santa Clara' tomato seeds were sown in polystyrene trays containing commercial substrate to obtain seedlings. After 25 days, seedlings were transplanted to plastic pots $(2 \mathrm{~L})$ containing a sterilized mixture of soil, sand, and organic compound $(2: 2: 1)$, sterilized by autoclaving at 120 ${ }^{\circ} \mathrm{C}$ and $1 \mathrm{~atm}$ for 1 hour. At the time of transplanting, the root system of the tomato seedlings were dipped in $0.1 \%$ treatment solution ( $1 \mathrm{~mL}$ of solution diluted in $1 \mathrm{~L}$ of distilled water) (BONATO et al., 2009) and were then planted in pots. In 2013, three days after the treatment and planting, seedlings were inoculated with $1 \mathrm{~mL}$ of nematode suspension containing approximately 4,850 eggs and second stage juveniles (J2), distributed in two holes near the plant. In 2014, after seven days of planting, seedlings were inoculated with $1.2 \mathrm{~mL}$ of suspension containing approximately 5,050 eggs and J2. 
Subsequently, weekly sprays of the treatment were performed, with a $0.1 \%$ solution used on the plant shoots, without any runoff of treatment on to the soil surface. The infestation level (egg mass rate) was evaluated after 40 days of inoculation. In 2013, the plants were left for 50 days in the pots after the nematode inoculation, and in 2014 the plants were left for 40 days.

The evaluated biometric parameters were plant height, fresh and dry weight of shoots, fresh weight of roots, number of clusters, number of fruits per cluster, fresh and dry weight of fruits, and relative chlorophyll content. Phytopathological parameters evaluated were number of egg masses, numbers of eggs and $\mathrm{J} 2$ at $100 \mathrm{~cm}^{3}$ of soil, number of eggs and $\mathrm{J} 2$ presents at the roots, and number of galls at the roots.

The relative chlorophyll content was evaluated using a SPAD-502 Konica Minolta, on the 44th day, using the fourth leaf from the apex to the base of the plant.

To count the egg masses, the roots were dipped in a $0.015 \%$ solution of Phloxine B dye for 15 minutes (TAYLOR; SASSER, 1978). After that, the roots were removed and washed in running water, and the count was performed using a stereomicroscope.

To evaluate the number of nematodes and eggs in the roots, the roots were cut into small pieces and liquefied in an industrial blender for 20 seconds at maximum speed. The blended material was then poured into a sieve with a 400-sized mesh $(0.037$ $\mathrm{mm}$ mesh), which was then washed with a spray of water. The collected material from the sieve was subjected to the centrifugal flotation method in sucrose solution (FREITAS et al., 2007). The count was performed on Peters' counting slide under an optical microscope. Nematodes were extracted from the soil using centrifugal flotation in a sucrose solution (TIHOHOD, 1989; 1993). The count was performed on Peters' counting slide under an optical microscope.

In 2014, similar assays were performed to those detailed above, for destructive evaluation of tomato roots. The experimental design was a randomized complete block with eight treatments $(6,12,24,50$, $100,200,400 \mathrm{CH}$ and control), and three replicates per treatment. The area under the enzymatic activity curve (AAEAC) was determined using the equation $\Sigma[($ enzymatic activity at time $2-$ enzymatic activity at time 1) / 2) * (time 2 - time 1)], for the enzymes: peroxidase, polyphenol oxidase and phenylalanine ammonia-lyase. The data were submitted to analysis of variance and the means were compared using the Tukey test at $5 \%$ probability.

The roots were collected at 72, 108 and 144 hours after the treatment. The inoculation with approximately 5050 eggs and $\mathrm{J} 2$ of $M$. incognita for each plant was done three days after the treatment. At the time of collection, the roots were washed in running water, slightly wrapped in aluminum foil and frozen in liquid nitrogen, and then stored in a freezer at $-20^{\circ} \mathrm{C}$.

The protein extracts, used for the subsequent enzymatic analyzes and protein content, were obtained by maceration of the roots in liquid nitrogen, which were then homogenized in $4 \mathrm{~mL}$ of $0.01 \mathrm{M}$ sodium phosphate buffer ( $\mathrm{pH}$ 6.0) (extraction buffer), adding $0.04 \mathrm{~g}$ of polyvinylpyrrolidone during maceration. The homogenate was centrifuged at 20,000 $\mathrm{g}$ for $20 \mathrm{~min}$ at $4{ }^{\circ} \mathrm{C}$ (LUSSO; PASCHOLATI, 1999).

Peroxidase activity (POX) was determined at 30 ${ }^{\circ} \mathrm{C}$, with the assay solution mixture comprising 2.9 $\mathrm{mL}$ enzyme substrate $(306 \mu \mathrm{L}$ hydrogen peroxide, $12.5 \mathrm{~mL}$ guaiacol, $2 \%$ alcoholic, and $87.5 \mathrm{~mL}$ of $0.01 \mathrm{M}$ phosphate buffer [pH 6.0]), and 0.1 $\mathrm{mL}$ of protein extract. The reaction was read in a spectrophotometer at $470 \mathrm{~nm}$, with readings taken every 15 seconds for 2 minutes. The results were expressed as variation of unit of absorbance (abs), abs $\min ^{-1} \mathrm{mg}$ protein ${ }^{-1}$ (HAMMERSCHIMIDT et al., 1982).

The polyphenoloxidase activity (PFO) was determined using the methodology of Duangmal and Apeten (1999). The assay measured the oxidation 
of catechol to quinone, a reaction mediated by the enzyme polyphenoloxidase. The reaction temperature was $30{ }^{\circ} \mathrm{C}$, and spectrophotometer readings were taken at $420 \mathrm{~nm}$ for a period of $2 \mathrm{~min}$. Activity was expressed as variation of abs $\min ^{-1} \mathrm{mg}$ protein $^{-1}$.

Phenylalanine ammonia-lyase activity (PAL) was determined according to the methodology described by Umesha (2006), in which $100 \mu \mathrm{L}$ of the protein extract was added to $400 \mu \mathrm{L}$ of 0.025 $\mathrm{M}$ Tris- $\mathrm{HCl}$ buffer $(\mathrm{pH} 8.8)$ and $500 \mu \mathrm{L}$ of a 0.05 $\mathrm{M}$ solution of L-phenylalanine. This mixture was incubated at $40{ }^{\circ} \mathrm{C}$ for 2 hours. After 2 hours, $60 \mu \mathrm{L}$ of $5 \mathrm{M} \mathrm{HCl}$ was added to stop the reaction, followed by spectrophotometer measurement at $290 \mathrm{~nm}$.

The total protein content was obtained using the method of Bradford (1976), mixing $600 \mu \mathrm{l}$ of 0.01 M phosphate buffer ( $\mathrm{pH} 6.0$ ), $200 \mu \mathrm{l}$ of enzyme preparation, and $200 \mu \mathrm{l}$ of Bradford reagent. After incubation for $5 \mathrm{~min}$ and shaking, absorbance was read in a spectrophotometer at $595 \mathrm{~nm}$. Each sample consisted of three replicates.

Data analysis was performed using the Lilliefors normality test and analysis of variance, separately for each experiment. The Tukey test with a significance level of 5\% was used. Analyses were undertaken using the statistical program SISVAR (FERREIRA, 2011).

The in vitro assay was performed using a completely randomized experimental design, with eight treatments and four replicates, resulting in a total of 32 plots, with each plot consisting of a $50 \mathrm{~mL}$ sterile plastic bottle. The treatments were composed of the homeopathic preparation of $T$. occidentalis in Hahnemannian dynamizations of 6 , $12,24,50,100,200$ and $400 \mathrm{CH}$ in a $0.1 \%$ solution (as previously described), and the control treatment (distilled water).

For the evaluation of hatched J2 M. incognita, each bottle contained $10 \mathrm{~mL}$ of solution for each treatment, and $1 \mathrm{~mL}$ of the nematode suspension with approximately $250 \mathrm{~mL}^{-1}$ eggs. The bottles were kept at $25{ }^{\circ} \mathrm{C}$ for 15 days. After this period, the percentage of $\mathrm{J} 2$ hatched was evaluated under a optical microscope.

The J2 used for evaluation of mortality and motility were obtained through the Baermann funnel methodology, which uses a size 102 coffee filter paper on a funnel (FREITAS et al., 2007). For the motility evaluation, $1 \mathrm{~mL}$ of nematode suspension containing approximately $120 \mathrm{~J} 2$ of $M$. incognita was placed along with $10 \mathrm{~mL}$ of each treatment in each sterile bottle. After 24 hours, the percentage of apparently immobile nematodes was evaluated. Then, for mortality evaluation, the J2 were deposited in a 400 mesh sieve where the treatment was replaced with tap water, and put back into the bottles for another 24 hours. The $\mathrm{J} 2$ that remained immobile or rectilinear or that presented unusual appearance were considered dead (FRANZENER et al., 2007). The evaluations were performed using an optical microscope and Peters counting slides. Data were analyzed in the same manner as the in vivo experiment.

The analysis of variance and Tukey's test indicated a significant difference between homeopathic treatments and the control treatment ( $p \leq 0.05$ ) only for the variables of egg mass, and number of $\mathrm{J} 2$ per root and per $100 \mathrm{~cm}^{3}$ of soil (Table $1)$.

In 2013, the control treatment showed lower numbers of egg masses than did treatments using T. occidentalis $200 \mathrm{CH}$ and $400 \mathrm{CH}$, and was similar to other dynamizations (Table 1). Similar behavior was observed by Swarowsky et al. (2014) when studying the use of different dynamizations of Cina on $M$. incognita infected tomato shoots. That study found more eggs of nematodes in plants that had been submitted to homeopathic treatments than in those submitted to the water control treatment. These authors associated this effect with the presence of ethanol in the homeopathic treatment, since the mean of the homeopathic treatments and that of the $70 \%$ ethanol control were similar. However, in the present 
work, the control treatment used was distilled water, without ethanol. This nonetheless showed the same effect. These results may be associated with the fact that the homeopathic preparation of $T$. occidentalis had been chosen by analogy with the symptoms of diseased plants, that is, the presence of galls. Homeopathic treatment is aimed at the treatment of the symptoms of the sick individual (BONATO, 2007), not the causal agent, which can therefore explain the absence of effects on the pathogen. As reported by Teixeira (2011), a homeopathic preparation acts by therapeutic similarity, and aims to induce curative homeostasis against the disease, inducing the body to react against its own disorders, not by direct action against the pathogen, which would explain the result here obtained.

For the values of $\mathrm{J} 2$ in the roots, the control treatment statistically differed from $50 \mathrm{CH}$ and $100 \mathrm{CH}$, with a higher value. The treatment $100 \mathrm{CH}$ produced the lowest mean followed by $50 \mathrm{CH}$, differing from the water control with $64.19 \%$ and $48.17 \%$ reductions of $\mathrm{J} 2$ in the roots, respectively, for the first experiment (2013). In the second experiment, no statistical differences were found between the homeopathic treatments and the control treatment for $\mathrm{J} 2$ in the roots (Table 1).

Table 1. Number of egg masses (EM) and second stage juveniles (J2) presents in the soil and roots of tomato plants treated with dynamizations of Thuya occidentalis, in 2013 and 2014.

\begin{tabular}{|c|c|c|c|c|c|c|c|c|c|c|}
\hline \multirow{2}{*}{$\begin{array}{l}\text { Treatments } \\
\text { T. occidentalis }(\mathrm{CH})^{* *}\end{array}$} & \multicolumn{2}{|c|}{ EM (2013) } & \multicolumn{2}{|c|}{ EM (2014) } & \multicolumn{2}{|c|}{ J2 (2013) } & \multicolumn{2}{|c|}{$\mathrm{J} 2^{*}(2013)$} & \multicolumn{2}{|c|}{$\mathrm{J} 2^{*}(2014)$} \\
\hline & \multicolumn{6}{|c|}{ - n / roots - - } & \multicolumn{4}{|c|}{$-\mathrm{n}^{\circ} / 100 \mathrm{~cm}^{3}$ of soil ---- } \\
\hline 6 & 438.7 & $\mathrm{abc}$ & 827.3 & $\mathrm{ab}$ & 159.7 & $a b c$ & 12.6 & $\mathrm{a}$ & 26.3 & $\mathrm{ab}$ \\
\hline 12 & 388.5 & $\mathrm{bc}$ & 1039.6 & $a b$ & 125.0 & $\mathrm{abc}$ & 10.1 & $a b$ & 17.0 & $\mathrm{bc}$ \\
\hline 24 & 442.7 & $\mathrm{abc}$ & 1106.3 & $a b$ & 152.7 & $\mathrm{abc}$ & 7.5 & $a b$ & 24.8 & $\mathrm{abc}$ \\
\hline 50 & 397.2 & $\mathrm{bc}$ & 1001.0 & $a b$ & 110.0 & $\mathrm{bc}$ & 7.8 & $a b$ & 18.9 & $a b c$ \\
\hline 100 & 406.0 & $\mathrm{bc}$ & 788.0 & $\mathrm{~b}$ & 76.0 & $\mathrm{c}$ & 4.5 & $\mathrm{~b}$ & 13.1 & $\mathrm{c}$ \\
\hline 200 & 462.5 & $a b$ & 1073.3 & $a b$ & 178.5 & $a b$ & 7.7 & $a b$ & 24.2 & $a b c$ \\
\hline 400 & 531.2 & $\mathrm{ab}$ & 1222.3 & $\mathrm{a}$ & 141.2 & $\mathrm{abc}$ & 9.1 & $a b$ & 22.5 & $\mathrm{abc}$ \\
\hline Control (water) & 344.7 & $\mathrm{c}$ & 869.3 & $a b$ & 212.2 & $\mathrm{a}$ & 8.5 & $\mathrm{ab}$ & 30.9 & $\mathrm{a}$ \\
\hline Mean & 426.47 & & 990.91 & & 144.44 & & 8.49 & & 22.24 & \\
\hline CV $(\%)$ & 11.65 & & 15.17 & & 29.58 & & 28.26 & & 20.17 & \\
\hline
\end{tabular}

In the column, means followed by the same letter do not differ by the Tukey test at $5 \%$ of probability.

*Values transformed into

$* * \mathrm{CH}=$ centesimal Hahnemannian.

As the control treatment (water) had produced lower values of egg masses in the roots in 2013, it was concluded that homeopathic $T$. occidentalis treatments were not able to interfere in the development of the pathogen, or at least that of the J2 that penetrated the plant's roots when inoculated in the first days of treatment. This may be because the homeopathic preparation contributed to the homeostasis of the host plant, and did not act directly on the pathogen, as discussed previously.

Studies of nematode control in vivo with the use of $T$. occidentalis homeopathic preparations have not been reported in the literature, but there are some studies, such as that by Sukul et al. (2006), which have shown the potential of homeopathy for nematode control. These authors verified that the homeopathic treatments Cina and Santonin, both in $30 \mathrm{CH}$ dynamizations, sprayed on the shoot of Abelmoschus esculentus (L.) Moench (synonym: Hibiscus esculentus L.) plants for 10 consecutive days controlled $M$. incognita. They concluded that Cina was able to reduce the population of this nematode by producing conditions unfavorable to the pathogen in the root. A study by Datta (2006) 
also showed a decrease in $M$. incognita populations in the roots of mulberries treated on the shoots with the homeopathic treatment Cina $200 \mathrm{CH}$, and with a mother tincture of Cina. Thus, in this work and in that of Sukul et al. (2006) and Datta (2006), considering that the homeopathic dilutions were applied to the shoots of the plant, i.e. with no contact with the pathogen in the soil, we assumed the occurrence of resistance induction. This supposition will be discussed later, based on the results of enzymatic activity.

The number of $\mathrm{J} 2$ in the soil was lower with the $100 \mathrm{CH}$ dynamization than with the $6 \mathrm{CH}$ dynamization in 2013, with a reduction of $64.3 \%$, though it was not different from that of the control treatment (Table 1). In 2014, the $100 \mathrm{CH}$ dynamization also showed the lowest mean among the treatments; this was different from the means of the $6 \mathrm{CH}$ dynamization and the water control, with reductions of $50.20 \%$ and $57.63 \%$, respectively.

The hatching of nematodes only occurs when environmental conditions, such as temperature, oxygen, and soil moisture, are favorable. Root exudates also can affect and induce the hatching rate of Meloidogyne under conditions such as diapause where there are no physiological barriers. Diapause is a stage where development is inhibited until the specific favorable conditions required by the nematodes are present again (CURTIS et al., 2009). Therefore, the dynamization of $100 \mathrm{CH}$ could have created unfavorable conditions in the plant for the hatching of the J2. This may occur because of, for example, a probable change in the exudates released by the roots (WUYTS et al., 2006), which is then reflected in the smaller numbers of $\mathrm{J} 2$ in the soil.

The variable numbers of galls and number of eggs in the roots and soil in 2013 were not significantly different at $5 \%$ probability by the
Tukey test. The same variables also did not differ in the year 2014, nor did the number of $\mathrm{J} 2$ in the roots (data not shown).

The variables related to plant growth that showed significantly higher values in the year 2013 were root volume, and fresh and dry weight of fruits (Table 2). There were no statistically significant differences between homeopathic treatments and the control treatment for the other plant growth variables, including plant height, fresh and dry weights of shoots, number of clusters, number of fruits per cluster and relative chlorophyll content. In 2014, root volume and fresh weight of shoots showed statistically significantly higher differences.

In 2013, the T. occidentalis $200 \mathrm{CH}$ dynamization showed significantly higher root volume than the control and $12 \mathrm{CH}$ and $50 \mathrm{CH}$ treatments, with increases of $29.23 \%, 37.43 \%$, and $30.76 \%$, respectively (Table 2 ). There were no statistically significant differences in this variable between the $6,24,100$, and $400 \mathrm{CH}$ treatments. In 2014, for root volume, $12 \mathrm{CH}$ dynamization had the lowest mean; this was significantly lower than that of the $100 \mathrm{CH}$ dynamization; however, no homeopathic treatments differed significantly from the control treatment (Table 2).

Although one of the homeopathic treatments caused an increase in root volume in 2013, this was not observed in 2014. According Carneiro et al. (2011), experiments with homeopathy have been reproducible and have generated significant results, but in some cases opposite effects are found to what would be expected. Baumgartner et al. (2008) state that the reproducibility of homeopathy experiments is a complex situation, because of factors such as differences in weather, requiring an interactive approach. This could well explain the differences in responses between the 2013 and 2014 trials for some variables. 
Table 2. Root volume (RV), dry weight of fruits (DWF), fresh weight of fruits (FWF) and fresh weight of shoots (FWS) of tomato plants infected with M. incognita and treated with dynamizations of Thuya occidentalis, in the years of 2013 and 2014.

\begin{tabular}{|c|c|c|c|c|c|c|c|c|c|c|}
\hline \multirow{2}{*}{$\begin{array}{l}\text { Tratamentos } \\
\text { T. occidentalis }(\mathrm{CH})^{*}\end{array}$} & \multicolumn{2}{|c|}{ RV (2013) } & \multicolumn{2}{|c|}{ RV (2014) } & \multicolumn{2}{|c|}{ DWF (2013) } & \multicolumn{2}{|c|}{ FWF (2013) } & \multicolumn{2}{|c|}{ FWS (2014) } \\
\hline & \multicolumn{4}{|c|}{------- mL / plant ------- } & \multicolumn{6}{|c|}{-------------------- g / plant -------------------- } \\
\hline 6 & 40.5 & $\mathrm{abc}$ & 29.6 & $a b$ & 9.5 & $\mathrm{a}$ & 131.4 & $\mathrm{abc}$ & 96.3 & $a b$ \\
\hline 12 & 30.5 & $\mathrm{c}$ & 19.0 & $\mathrm{~b}$ & 8.9 & $a b$ & 121.9 & $a b c$ & 85.0 & $\mathrm{~b}$ \\
\hline 24 & 44.7 & $a b$ & 29.6 & $a b$ & 9.7 & $\mathrm{a}$ & 147.6 & $a b$ & 97.0 & $a b$ \\
\hline 50 & 33.7 & $\mathrm{bc}$ & 25.0 & $a b$ & 7.3 & $\mathrm{~b}$ & 98.0 & $\mathrm{c}$ & 97.6 & $\mathrm{a}$ \\
\hline 100 & 43.2 & $\mathrm{abc}$ & 30.6 & $\mathrm{a}$ & 8.7 & $a b$ & 126.8 & $a b c$ & 93.3 & $a b$ \\
\hline 200 & 48.7 & $\mathrm{a}$ & 29.3 & $a b$ & 9.4 & $\mathrm{a}$ & 150.3 & $\mathrm{a}$ & 93.0 & $a b$ \\
\hline 400 & 40.0 & $\mathrm{abc}$ & 25.0 & $a b$ & 8.8 & $a b$ & 102.2 & $\mathrm{bc}$ & 96.0 & $a b$ \\
\hline Controle (água) & 34.5 & $\mathrm{~b} \mathrm{c}$ & 21.6 & $a b$ & 7.8 & $a b$ & 100.9 & $\mathrm{c}$ & 91.3 & $a b$ \\
\hline Mean & 39.50 & & 26.25 & & 8.82 & & 122.43 & & 93.71 & \\
\hline CV (\%) & 13.81 & & 14.28 & & 10.16 & & 16.17 & & 4.60 & \\
\hline
\end{tabular}

In the column, means followed by the same letter do not differ by the Tukey test at $5 \%$ of probability.

$* \mathrm{CH}=$ centesimal Hahnemannian.

Some studies on the use of homeopathy in plants have already investigated the tonic effect that highly diluted preparations are able to promote, and have found similar results. One such study is that of Swarowsky et al. (2014), who observed that the Cina 12, 24, 200 and $400 \mathrm{CH}$ dynamizations promoted a greater volume of roots in tomatoes than the control. Another study on the stimulating effect of these highly diluted substances on plant growth was undertaken by Bonato and Silva (2003), in which dynamizations of Suphur were shown to lead to an increase in radish root diameter. The same authors reported that although some dynamizations favored plant growth, others did not have this effect. This was attributed to the characteristic action of homeopathic treatments, because when there is similarity between the homeopathic treatment and the sick individual being treated, the body's vital energy responds as opposed to the energy of the homeopathic treatment to act against its own disease. When there is no similarity, there may be disorder in the metabolic system of the plant, and this will result in a negative response in the growth and development of the plant.

In 2013 , the $24 \mathrm{CH}$ and $200 \mathrm{CH}$ dynamizations showed the highest means for fresh weight of fruits, with significant increases of $46.25 \%$ and $49 \%$, respectively, in relation to the control treatment. The homeopathic treatment $T$. occidentalis $200 \mathrm{CH}$ showed larger amounts of egg masses than the control treatment (Table 1), but also promoted an increase in root volume and fresh weight of fruits. Thus, it seems that this dynamization promoted stabilization of infected tomato plants, with better growth conditions, that supported the nematode infection without affecting the plant's development, showing a possible tonic effect as reported by Toledo et al. (2011). Utilizing this same hypothesis, Boff et al. (2008) tested different homeopathic treatments, including T. occidentalis, on tomatoes to control pests and diseases, and found that a $60 \mathrm{CH}$ dynamization applied fortnightly produced the highest fruit yield, of $26 \mathrm{Mg} \mathrm{ha}^{-1}$, an increase of $19.93 \%$ in comparison to that of the control treatment.

Datta (2006) found statistically significant differences for the fresh biomass of shoots in mulberry plants treated with Cina $200 \mathrm{CH}$ and mother tincture of Cina from the control, which, in addition to showing potential for nematode control, also improved the growth of the plants. Greater lengths of shoot and root, as well as greater fresh weights of shoot and root, were evident in the treatments. Panda et al. (2013) evaluated the possible effect 
of three dynamizations of homeopathic treatments Arsenicum album and Baryta carbonica on pea (Pisum sativum L.) growth, and all treatments increased the fresh weight of the plants, and influenced the photosynthetic rate.

In 2014, all the homeopathic treatments were statistical similar to control treatment for the fresh weight of shoots (Table 2).

It is interesting to observe that the plants treated with the different dynamizations showed different behaviors depending on the year, and that some dynamizations promoted increases in particular biometric parameters, while others had no effect. This behavior is typical of homeopathy, and has already been seen in other studies, where the same substance causes different effects according to the dynamization used, either stimulating beneficial reactions or showing negligible results (BONATO, SILVA, 2003).

Building on the idea that dynamizations may offer improvements in plant growth, Müller and Toledo (2013) noticed that some homeopathic preparations are efficient at increasing the development of the plants, notably by increasing the number of fruits, promoting the growth of shoots and the root system, and assisting with the control of pests and diseases in the production of tomatoes in greenhouses. This information helps to better understand the potential of homeopathy, which in this study showed that specific dynamizations of $T$. occidentalis promoted increases in some aspects of tomato growth, varying according to the year of the experiment.

In the biochemical analyses, the homeopathic treatments $T$. occidentalis $24,50,200$, and $400 \mathrm{CH}$ showed the highest values for peroxidase activity
(POX), differing significantly from the control treatment (Figure 1). Changes in the activity of peroxidases are generally correlated with the defense response of plants against pathogens (STANGARLIN et al., 2011). These enzymes prevent the attack of pathogens and improve the physical barriers of the plant by generating reactive oxygen species (ROS), regulating $\mathrm{H}_{2} \mathrm{O}_{2}$ levels, polymerizing phenolic compounds to form lignin, and increasing the cell wall hardness (PASSARDI et al., 2005). However, this result cannot be related to the decrease of $\mathrm{J} 2$ in the tomato roots caused by the $50 \mathrm{CH}$ dynamization (Table 1), since the other dynamizations did not show this same behavior. Therefore, the peroxidase activity alone cannot be considered responsible for the control of $\mathrm{J} 2$ in the roots.

Other studies report the induction of resistance in plants against pathogens being promoted by homeopathic treatments, through the activation of secondary metabolism, eliciting some enzymes related to plant defenses such as the production of tannins, essential oils, and other defense compounds (CASTRO et al., 2001, OLIVEIRA et al., 2014).

For polyphenoloxidase activity (PFO), the homeopathic treatment that showed the best result was the $200 \mathrm{CH}$ dynamization, with 2.95 times statistically higher activity than the control treatment. PFO activity in the other treatments was identical to that in the control (Figure 1). Similar to peroxidase activity the increase in polyphenoloxidase in the roots of the $200 \mathrm{CH}$ treatment did not have a negative impact on $\mathrm{J} 2$ of $M$. incognita, since $200 \mathrm{CH}$ did not exhibit control of the nematodes in the studied pathosystem. 
Figure 1. Area under the curve of enzymatic activity (AUCEA) for peroxidase (POX), polyphenoloxidase (PFO) and phenylalanine ammonia-lyase (PAL) for tomato roots treated with dynamizations of Thuya occidentalis and inoculated with $M$. incognita. Means followed by the same letter do not differ by the Tukey test at $5 \%$ of probability. $\mathrm{CH}$ : Hahnemannian centesimal. The bars represent the standard error of the mean.

\section{POX}
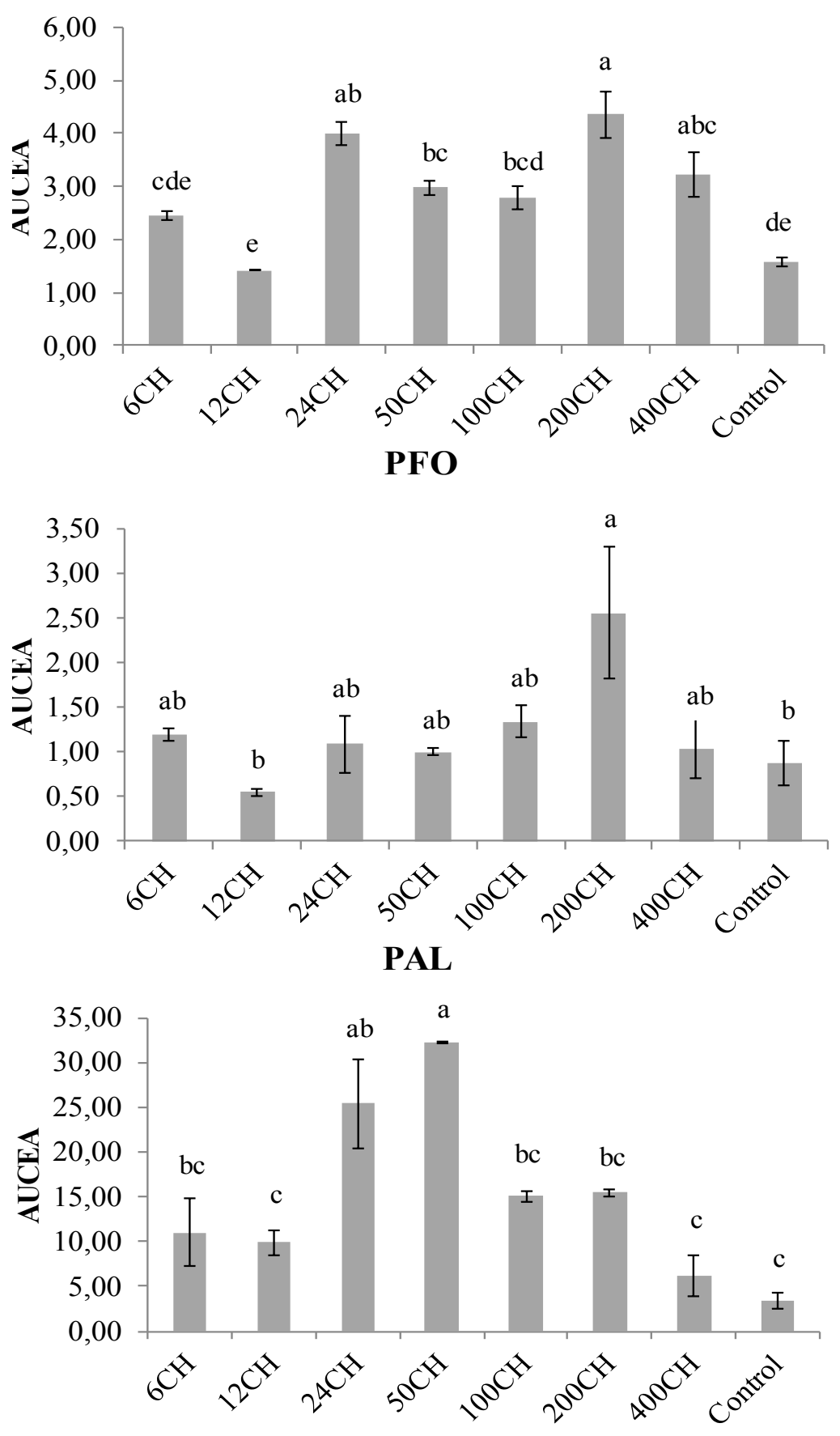

Thuya occidentalis 
With regard to phenylalanine ammonia-lyase (PAL), Figure 1 shows that the $24 \mathrm{CH}$ and $50 \mathrm{CH}$ dynamizations elicited the best results, with statistically significantly higher activity than that of the control treatment. The highest activity for this defense enzyme was observed in the $50 \mathrm{CH}$ treatment, with values 9.56 times higher than those of the control. This impressive result may explain the control responses of $\mathrm{J} 2$ in the root as observed in Table 1.

Tomato genotypes resistant to Meloidogyne have high levels of phenylalanine ammonia-lyase, the key enzyme for the production of phenolic compounds, which are related to plant resistance to disease. Thus, the high amount of phenols synthesized in the plant and translocated to the roots may confer resistance against nematode infection (ARIAS et al., 2009).

Kalaiarasan (2009) tested the resistance of 42 genotypes of tomato against $M$. incognita and found greater PAL activity in resistant genotypes. This is the enzyme considered to be the most important in the synthesis of phenols, phytoalexins, phenylpropanoids and lignins, POX and PFO were observed to increase in both susceptible and resistant genotypes. This indicates the importance of PAL in plant resistance against nematodes.

Homeopathic treatments appear to be a promising alternative in the control of phytopathogens through the induction of resistance in plants, showing positive results in other pathosystems. Examples of such results include increases of phenylalanine ammonia-lyase in the common bean, using Corymbia citriodora (synonym: Eucalyptus citriodora Hook.) $24 \mathrm{CH}$ and Calcarea carbonica 12, 24, 30 and 60CH (OLIVEIRA et al., 2014), and in Dimorphandra mollis Benth using Sulphur $12 \mathrm{CH}$ and Phosphorus 12CH (DAS DÔRES, 2007).

According to Balbi-Peña et al. (2006), the use of products that can control plant diseases through resistance induction by eliciting the production of key compounds, and which have low environmental impact and low toxicity to living beings, is considered a promising alternative for agriculture.

No significant differences were found for in vitro tests of motility and mortality of $\mathrm{J} 2$ and eggs hatch. Ray and Pradhan cited by Betti et al. (2009), when conducting in vitro experiments, tested unspecified dynamizations of 15 homeopathic treatments, including $T$. occidentalis, against root-knot nematode. This study showed potential mortality of $26 \%$ for $\mathrm{J} 2$, which can be considered a low direct toxicity.

Currently, when choosing a homeopathic treatment to be used, the symptoms presented by a plant infected with root-knot nematode were considered and not the pathogen itself, since the treatment was expected to have no direct influence on the nematode (BONATO, 2007).

In summary, the homeopathic treatment $T$. occidentalis $100 \mathrm{CH}$ dynamization caused a reduction in the $\mathrm{J} 2$ population of $M$. incognita in the roots and soil. Some dynamizations of this homeopathic treatment interfered with the growth of the tomato plant, whilst $200 \mathrm{CH}$ increased the volume of root and fresh weight of fruits, and $24 \mathrm{CH}$ increased the fresh weight of fruit. In addition, homeopathic treatments increased the activity of some plant defense related enzymes. $T$. occidentalis $24,50,200$, and $400 \mathrm{CH}$ promoted an increase of peroxidase, $200 \mathrm{CH}$ increased polyphenoloxidase, while 24 and $50 \mathrm{CH}$ also increased levels of phenylalanine ammonia-lyase. Thuya occidentalis, in all the dynamizations tested, did not demonstrate any direct toxic effects on $M$. incognita $\mathrm{J} 2$ or eggs.

The authors thank the Higher Education Personnel Improvement Coordination, CAPES, for the first author's Masters scholarship. We thank the Araucária Foundation of Support to the Scientific and Technological Development of the State of Paraná for the financial support to the project $(\mathrm{CV}$ 123/2014). We thank the National Council for Scientific and Technological Development (CNPq) for the JRS research productivity scholarship. 


\section{References}

ARIAS, Y.; GONZÁLEZ, I.; RODRÍGUEZ, M.; ROSALES, C.; SUÁREZ, Z.; PETEIRA, B. Aspectos generales de la interacción tomate (Solanum lycopersicum L.) - Meloidogyne incognita. Revista de Protección Vegetal, La Habana, v. 24, n. 1, p. 1-13, 2009.

BALBI-PEÑA, M. I.; BECKER, A.; STANGARLIN, J. R.; FRANZENER, G.; LOPES, M. C.; SCHWANESTRADA, K. R. F. Controle de Alternaria solani em tomateiro por extratos de Curcuma longa e curcumina II. Avaliação in vivo. Fitopatologia Brasileira, Brasília, v. 31, n. 4, p. 401-404, 2006.

BAUMGARTNER, S.; SHAH, D.; SCHALLER, J.; KAMPFER, U.; THURNEYSEN, A.; HEUSSER, P. Reproducibility of dwarf pea shoot growth stimulation by homeopathic potencies of gibberellic acid. Complementary Therapies in Medicine, London, v. 16, n. 4, p. 183-191, 2008.

BETTI, L.; TREBBI, G.; MAJEWSKY, V.; SCHERR, C.; SHAH-ROSSI, D.; JÄGER, T.; BAUMGARTNER, S. Use of homeopathic preparations in phytopathological models and in field trials: a critical review. Homeopathy, London, v. 98, n. 4, p. 244-266, 2009.

BOERICKE, W. Manual de matéria médica homeopática. Tomo II. 9. ed. São Paulo: Robe Editorial, 2003. 638 p.

BOFF, P.; MADRUGA, E.; ZANELATO, M.; BOFF, M. I. C. Pest and disease management of potato crops with homeopathic preparations and germplasm variability. In: IFOAM ORGANIC WORLD CONGRESS, 16., 2008, Modena. Proceeding... Modena: ISOFAR, 2008. p. 544547. v. 1.

BONATO, C. M. Homeopatia em modelos vegetais. Cultura Homeopática, São Paulo, v. 6, n. 21, p. 24-28, 2007.

BONATO, C. M. PROENÇA, G. T.; REIS, B. Homeopathic homeopathic drugs Arsenicum album and Sulphur affect the growth and essential oil content in mint (Mentha arvensis L.). Acta Scientiarum. Agronomy, Maringá, v. 31, n. 1, p. 101-105, 2009.

BONATO, C. M.; SILVA, E. P. Effect of the homeopathic solution Sulphur on the growth and productivity of radish. Acta Scientiarum. Agronomy, Maringá, v. 25, n. 2, p. 259-263, 2003.

BRADFORD, M. M. A rapid and sensitive method for the quantitation of microgram quantities of protein utilizing the principle of protein-dye binding. Analytical Biochemistry, New York, v. 72, n. 1-2, p. 248-254, 1976.

CARNEIRO, S. M. T. P. G.; OLIVEIRA, B. G.; FERREIRA, I. F. Efeito de medicamentos homeopáticos, isoterápicos e substâncias em altas diluições em plantas: revisão bibliográfica. Revista de Homeopatia, São Paulo, v. 74, n. 1-2, p. 9-32, 2011.

CARNEIRO, S. M. T. P. G.; ROMANO, E. D. B.; PIGNONI, E.; TEIXEIRA, M. Z.; VASCONCELOS, M. E. C.; GOMES, J. C. Effect of biotherapic of Alternaria solani on the early blight of tomato-plant and the in vitro development of the fungus. International Journal of High Dilution Research, Guaratinguetá, v. 9, n. 33, p. 147-155, 2010.

CASTRO, D. M. Produção de óleo essencial e campo eletromagnético de capim-Limão (Cymbopogon citratus) tratado com soluções homeopáticas. In: Seminário Brasileiro Sobre Homeopatia Na Agropecuária Orgânica, 2., 2001, Espírito Santo do Pinhal. Anais... Viçosa: UFV, 2001. p. 165-174.

CHITWOOD, B. G. Root-knot nematodes-Part I. A revision of the genus Meloidogyne Göldi, 1887. Proceedings of Helminthological Society of Washington, Washington, v. 16, n. 2, p. 90-104, 1949.

CURTIS, R. H. C.; ROBINSON, A. F.; PERRY, R. N. Hatch and host location. In: PERRY, R. N.; MOENS, M.; STARR, J. L. (Ed.). Root-knot nematodes. Wallingford, Oxfordshire: CAB International, 2009. p. 139-162.

DAS DORES, R. G. R. Análise morfológica e fitoquímica de fava d'anta (Dimorphandra mollis Benth). 2007. Tese (Doutorado em Fitotecnia) - Universidade Federal de Viçosa, Viçosa.

DATTA, S. C. Effect of Cina on root-knot disease of mulberry. Homeopathy, London, v. 95, n. 2, p. 98-102, 2006.

DINIZ, L. P.; MAFFIA, L. A.; DHINGRA, O. D.; CASALI, V. W. D.; SANTOS, R. W. S.; MIZUBUTI, E. S. G. Avaliação de produtos alternativos para controle da requeima do tomateiro. Fitopatologia Brasileira, Lavras, v. 31, n. 2, p. 171-179, 2006.

DUANGMAL, K.; APENTEN, R. K. O. A comparative study of polyphenoloxidases from taro (Colocasia esculenta) and potato (Solanum tuberosum var. Romano). Food Chemistry, London, v. 64, n. 3, p. 351-359, 1999.

FERRAZ, L. C. C. B.; MONTEIRO, A. R. Nematoides. In: AMORIM, L.; REZENDE, J.A.M.; BERGAMIN FILHO, A. Manual de fitopatologia: princípios e conceitos. São Paulo: Agronômica Ceres, n. 13, p. $277-$ 305, 2011. v. 1.

FERREIRA, D. F. Sisvar: a computer statistical analysis system. Ciência e Agrotecnologia, Lavras, v. 35, n. 6, p. 1039-1042, 2011. 
FARMACOPÉIA HOMEOPÁTICA BRASILEIRA FHB. Métodos de preparações das formas farmacêuticas derivadas. 3. ed. São Paulo: Andrei, 2011. 364 p.

FRANZENER, G.; FRANZENER, A. S. M.; STANGARLIN, J. R.; FURLANETTO, C.; SCHWANESTRADA, K. R. F. Proteção de tomateiro a Meloidogyne incognita pelo extrato de Tagetes patula. Nematologia Brasileira, Piracicaba, v. 31, n. 1, p. 27-36, 2007.

FREITAS, L. G.; NEVES, W. S.; OLIVEIRA, R. D. L. Métodos em nematologia vegetal. In: ALFENAS, A. C.; MAFIA, R. G. Métodos em fitopatologia. Viçosa: UFV, 2007. p. 253-291.

HAMMERSCHIMIDT, T. R.; NUCLES, E. M.; KUC, J. Association of enhanced peroxidase activity with induced systemic resistance of cucumber to Colletotrichum lagenarium. Physiological Plant Pathology, London, v. 20, n. 1, p. 73-82, 1982.

KALAIARASAN, P. Biochemical markers for identification of root knot nematode (Meloidogyne incognita) resistance in tomato. Karnataka Journal of Agricultural Sciences, Krishinagar, v. 22, n. 3, p. 471475, 2009.

KARSSEN, G.; WESEMAEL, W.; MOENS, M. Rootknot nematode. In: PERRY, R. N.; MOENS, M. Plant nematology. Wallingford: CABI, 2013. p. 73-108.

KOFOID, C. A.; WHITE, W. A. Anew nematode infection of man. Journal of American Medical Association, Chicago, v. 72, n. 8, p. 567-569, 1919.

LORENZETTI, E.; STANGARLIN, J. R.; LORENZETTI TREIB, E.; HELING, A. L.; COLTRORONCATO, S.; CARVALHO, J. C.; HOEPERS, L.; RISSATO, B. B.; COPPO, J. C.; BELMONTE, C.; KUHN, O. J.; DA SILVA, I. F. Antimicrobial action against of Macrophomina phaseolina and control of the grey stem in soybean by homeopathic remedies Nosode and Sulphur. African Journal of Agricultural Research, Lagos, v. 11, n. 36, p. 3412-3417, 2016.

LUSSO, M. F. G.; PASCHOLATI, S. F. Activity and isoenzymatic pattern of soluble peroxidases in maize tissues after mechanical injury or fungal inoculation. Summa Phytopathologica, Botucatu, v. 25, n. 3, p. 244249, 1999.

MODOLON, T. A.; BOFF, P.; BOFF, M. I. C.; MIQUELLUTI, D. J. Homeophatic and high dilutions preparations for pest management to tomato crop under organic production system. Horticultura Brasileira, Brasília, v. 30, n. 1, p. 51-57, 2012.

MOENS, M.; PERRY, R. N.; STARR, J. L. Meloidogyne species - a diverse group of novel and important plant parasites. In: PERRY, R. N.; MOENS, M.; STARR, J. L.
Root-knot nematodes. CAB International: Wallingford, v. 1, n. 1, p. 1-17, 2009.

MULLER, S. F.; TOLEDO, M. V. Homeopatia na produção de tomate em cultivo protegido. Cadernos de Agroecologia, Porto Alegre, v. 8, n. 2, p. 1-4, 2013.

NASER, B.; BODINET, C.; TEGTMEIR, M.; LINDEQUIST, U. Thuya occidentalis (Arbor vitae): a review of its pharmaceutical, pharmacological and clinical properties. Evidence-based complementary and alternative medicine, New York, v. 2, n. 1, p. 69-78, 2005.

OLIVEIRA, J. S. B.; MAIA, A. J.; SCHWANESTRADA, K. R. F.; BONATO, C. M.; CARNEIRO, S. M. T. P. G.; PICOLI, M. H. S. Activation of biochemical defense mechanisms in bean plants for homeopathic preparations. African Journal of Agriculture Research, Lagos, v. 9, n. 11, p. 971-981, 2014.

PANDA, S. S.; MOHANTY, S. S.; DHAL, N. K. Effects of potentised homeopathic medicines on the germination, growth and photosynthetic activity of Pisum sativum L. Recent Research in Science and Technology, Humnabad, v. 5, n. 4, p. 11-14, 2013.

PASSARDI, F.; PENEL, C.; DUNAND, C. Peroxidases have more functions than a Swiss army knife. Plant Cell Reports, Berlin, v. 24, n. 5, p. 255-265, 2005.

RISSATO, B. B.; STANGARLIN, J. R.; COLTRORONCATO, S.; DILDEY, O. D. F.; GONÇALVES, E. D. V.; BROETTO, L.; KUHN, O. J.; LORENZETTI, E.; MIORANZA, T. M.; FIGUEIRA, E. P. P.; WEBLER, T. F. B.; LAURETH, J. C. U. Control of white mold in bean plants by homeopathic medicines. African Journal of Agricultural Research, Lagos, v. 11, n. 24, p. 21742178, 2016.

ROSSI, F.; AMBROSANO, E. J.; MELO, P. C. T.; GUIRADO, N.; MENDES, P. C. D. Experiências básicas de homeopatia em vegetais. Cultura Homeopática, São Paulo, v. 3, n. 7, p. 12-13, 2004.

STANGARLIN, J. R.; KUHN, O. J.; ASSI, L.; SCHWAN-ESTRADA, K. R. F. Control of plant diseases using extracts from medicinal plants and fungi. Science Against Microbial Pathogens: Communicating Current Research And Technological Advances, Badajoz, v. 2, n. 3, p. 1033-1042, 2011.

SUKUL, N. C.; CHAKRABORTY, I.; SUKUL, A. Potentized Cina reduces root-knot nematode in infestation of cucumber and the antinematode effect is transmitted through water. International Journal of High Dilution Research, Guaratinguetá, v. 12, n. 44, p. 133134, 2013.

SUKUL, N. C.; GHOSH, S.; SUKUL, A.; SINHABABU, S. P. Amelioration of root-knot disease of lady's finger 
plants by potentized Cina and Santonin. Homeopathy, London, v. 95, n. 3, p. 144-147, 2006.

SWAROWSKY, R. A.; STANGARLIN, J. R.; KUHN, O. J.; ESTEVEZ, R. L.; MIORANZA, T. M.; MÜLLER, M. A. Influence of high dilutions of Cina for the control of Meloidogyne incognita in tomato plants. American Journal of Plant Sciences, Irvine, v. 5, n. 25, p. 36953701, 2014.

TAYLOR, A. L.; SASSER, J. N. Biology, identification and control of root-knot nematodes (Meloidogyne sp.). Raleigh, North Carolina State University, 1978. 111 p.

TEIXEIRA, M. Z. Racionalidade científica no modelo homeopático. In: CARNEIRO, S. M. T. P. G. Homeopatia: princípios e aplicações na agroecologia. Londrina: IAPAR, 2011. cap. 3, p. 31-47.

TIHOHOD, D. Nematologia agrícola aplicada. Jaboticabal: FCAV, 1993. 372 p.

. Nematologia agrícola. Jaboticabal: FCAV, v. 1,

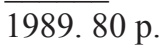

TOLEDO, M. V.; STANGARLIN, J. R.; BONATO, C. M. Homeopathy for the control of plant pathogens. Science Against Microbial Pathogens: Communicating Current Research And Technological Advances, Badajoz, v. 2, n. 3, p. 1063-1067, 2011.

UMESHA, S. Phenylalanine ammonia lyase activity in tomato seedlings and its relationship to bacterial canker disease resistance. Phytoparasitica, Bet Dagan, v. 34, n.1, p. 68-71, 2006.

WESEMAEL, W. M. L.; VIAENE, N.; MOENS, M. Root-knot nematodes (Meloidogyne spp.) in Europe. Nematology, Leiden, v. 13, n. 1, p. 3-16, 2011.

WUYTS, N.; SWENNEN, R.; WAELE, D. Effects of plant phenylpropanoid pathway products and selected terpenoids and alkaloids on the behavior of the plantparasitic nematodes Radopholus similis, Pratylenchus penetrans and Meloidogyne incognita. Nematology, Leiden, v. 8, n. 1, p. 89-101, 2006. 